\title{
Influence of biologicals on photosynthetic pigments in wheat leaves
}

Novikova I.I. ${ }^{1}$ Popova E.V. ${ }^{1}$, Kolesnikov L.E. ${ }^{2}$, Kolesnikova Yu.R. ${ }^{3}$

${ }^{1}$ All-Russian Scientific Research Institute of Plant Protection, Saint-Petersburg, Russia; ${ }^{2}$ St. Petersburg State Agrarian

University, Saint-Petersburg, Russia; ${ }^{3}$ Federal Research Center All-Russian Institute of Plant Genetic Resources N.I.

Vavilova", St. Petersburg, Russia

E-mail: irina_novikova@inbox.ru

Key message. Multifunctional biological products based on strains of microorganisms that are antagonists of pathogens and plant disease resistance activators - chitosan and its derivatives increase the content of chlorophyll $\alpha$ and $b$ in flag leaves of wheat, the number and weight of grains in the ear, potential yield, and also reduce the development of yellow rust. The maximum biological effectiveness for these indicators was noted in the experimental version, where Bacillus subtilis VKM B-2604D and B. subtilis VKM B-2605D strains that are part of the Vitaplan biological product and chitosan salicylate (Chitosan II) complex was used.

Keywords: soft wheat, multifunctional biological products, wheat productivity, wheat diseases, chlorophyll $\alpha$, chlorophyll b, carotenoids To increase productivity and protect crops from diseases, multifunctional biological products that combine the useful properties of strains of microorganisms' antagonists of pathogens and activators of plant disease resistance - chitosan and its derivatives are most promising. It is known that photosynthetic structures can participate in the formation of the plant's adaptive response to stress factors, including infection with phytopathogens and the development of pathogens, which is why it is important to study the effect of such multifunctional biological products (compositions) on photosynthetic plant pigments and the intensity of the development of diseases.

The purpose of the work was to study the effect of biological products and compositions, including Bacillus subtilis VKM B-2604D and B. subtilis VKM B-2605D strains that are part of the Vitaplan biological product and chitosan salicylate (Chitosan II) on the content of photosynthetic pigments in wheat leaves, productivity and yellow rust. For this, pre-sowing treatment of wheat seeds Leningradka 6 , $\mathrm{k}$ 64900 and 3-fold spraying of vegetating plants with preparations and multifunctional complexes: Vitaplanwettable powder - WP, "Vitaplan, CL" - culture liquid of B. subtilisB-2604D strain and B. subtilis B-2605D strain at ratio 1:1 with titer of live cells $\left(10^{10} \mathrm{CFU} \mathrm{ml}^{-1}\right)$, "Vitaplan, CL + Chitosan II", "Vitaplan CCL (concentrate of cultural liquid) + Chitosan II", in the future we compared the treated plants with the control, not subjected to treatment. The studies revealed a statistically significant increase in the content of photosynthetic pigments: chlorophyll $a$ and $\mathrm{b}$ in flag leaves of wheat with the use of biological products. The highest values of potential yield and content of chlorophyll $\alpha$ and $b$ in the leaves were determined in the experimental version, where the multifunctional complex "Vitaplan, CL + Chitosan II" was used. Correlation relationships were revealed, reflecting a decrease in the intensity of yellow rust development with an increase in the content of chlorophyll $\alpha$ and $b$ in the leaves, and also using the values of the Spearman criterion, the dominant effect of chlorophyll $b$ on the number of grains in an ear, the weight of grains of one ear, and the weight of an ear was shown.

\section{Влияние биопрепаратов на фотосинтетические пигменты в листьях пшеницы}

Новикова И.И. ${ }^{1}$, Попова Э.В. ${ }^{1}$, Колесников Л.Е. ${ }^{2}$, Колесникова Ю.Р. ${ }^{3}$

${ }^{1}$ Федеральное государственное бюджетное научное учреждение «Всероссийский научно-исследовательский институт защиты растений», Санкт-Петербург, Россия; ${ }^{2}$ ФББОУ ВО «Санкт-Петербургский государственный аграрный университет», Санкт-Петербург, Россия; ${ }^{3}$ ФБНУ «Федеральный исследовательский центр Всероссийский институт генетических ресурсов растений им. Н.И. Вавилова», Санкт-Петербург, Россия

\begin{abstract}
Аннотация. Полифункциональные биопрепаратьл на основе итаммов микроорганизмов-антагонистов возбудителей болезней и активаторов болезнеустойчивости растений - хитозана и его производных повышают содержание хлорофиллов $\alpha$ и b во флаговых листьях пшеницы, число и массу зерен в колосе, потенциальную урожайность, а также снижают развитие желтой ржавчины. Максимальная биологическая эффективность по этим показателям отмечена в варианте опыта, где был использован комплекс итаммов Bacillus subtilis BKM B-2604D и B. subtilis BKM B-2605D, входящих в состав биопрепарата Витаплан, и салицилата хитозана (Хитозан II).
\end{abstract}

Ключевые слова: мягкая пшеница, полифункииональные биопрепараты, урожайность пшеницы, болезни пшеницы, хлорофилл $а$, хлорофилл $b$, каротиноиды

Для повышения урожайности и защиты сельскохозяйственных культур от болезней наиболее перспективны полифункциональные биопрепараты, объединяющие полезные свойства штаммов микроорганизмов-антагонистов возбудителей болезней и активаторов болезнеустойчивости растений - хитозана и его производных. Известно, что фотосинтетические структуры могут участвовать в формировании адаптивного ответа растения на воздействие стрессовых факторов, в том числе - на инфицирование фитопатогенами и развитие возбудителей болезней, в связи с чем изучение влияния таких полифункциональных биопрепаратов (композиций) на фотосинтетические пигменты растений и интенсивность развития болезней, безусловно, актуально.

Цель работы - изучить влияние биопрепаратов и композиций, включающих штаммы Bacillus subtilis BKM B-2604D и B. subtilis BКМ B-2605D, входящих в состав биопрепарата Витаплан, и салицилата хитозана (Хитозан II) на содержание фотосинтетических пигментов в листьях растений пшеницы, ее продуктивность и пораженность желтой ржавчиной.

Для этого проводили предпосевную обработку семян пшеницы Ленинградка 6, к-64900 и 3-кратное опрыскивание вегетирующих растений препаратами и полифункциональными комплексами: «Витаплан, СП (смачивающийся порошок)», «Витаплан, КЖ (культуральная жидкость)», «Витаплан, КЖ + Хитозан ІІ», «Витаплан, КС (концентрат суспензии) + Хитозан ІІ», в дальнейшем сравнивали обработанные растения с контрольными, не подвергавшимися обработке. В результате проведенных исследований выявлены статистически достоверное повышение содержания фотосинтетических пигментов: хлорофилла $\alpha$ и $\mathrm{b}$ во флаговых листьях пшеницы при применении биопрепаратов. Наибольшие значения потенциальной урожайности и содержания в листьях хлорофилла $\alpha$ и b определены в варианте опыта, где был использован полифункциональный комплекс «Витаплан, КЖ + Хитозан II». Выявлены корреляционные связи, отражающие снижение интенсивности развития желтой ржавчины с увеличением содержания в листьях хлорофилла $\alpha$ и $\mathrm{b}$, а также с помощью значений критерия Спирмена показано доминирующее влияние хлорофилла b на число зерен в колосе, массу зерен одного колоса, а также массу колоса. 